\title{
Disease Development and Symptom Expression of Xanthomonas axonopodis pv. citri in Various Citrus Plant Tissues
}

\author{
C. J. Vernière, T. R. Gottwald, and O. Pruvost
}

First author: CIRAD-FLHOR, TA50/PS4, 34398 Montpellier cédex 5, France; second author: U.S. Department of Agriculture, ARS, Horticultural Research Laboratory, Fort Pierce, FL 34945; and third author: CIRAD, Pôle de Protection des Plantes (3P), 97410 Saint Pierre, La Réunion, France.

Accepted for publication 4 March 2003.

\begin{abstract}
Vernière, C. J, Gottwald, T. R., and Pruvost, O. 2003. Disease development and symptom expression of Xanthomonas axonopodis pv. citri in various citrus plant tissues. Phytopathology 93:832-843.

Experimental inoculations of Xanthomonas axonopodis pv. citri in different tissues of Tahiti lime and Pineapple sweet orange were conducted monthly under natural conditions on Réunion Island. The interactions between a set of environmental and epidemic variables associated with disease expression and 184 different factor combinations were investigated to determine the parameters needed to explain Asiatic citrus canker (ACC) disease expression. Area under the disease progress curve (AUDPC), inoculation date (Id), fruit and leaf age ratings (FAR and

analysis as the most meaningful epidemic and environmental variables, respectively. AUDPC as the strongest dependent variable and combinations of the environmental variables as independent variables were used in multiple regression analyses. Tissue age rating at the time of infection was a good predictor for disease resulting from spray inoculation on fruits and leaves and also on fruits following a wound inoculation. Temperature, as expressed by $T_{\min }$ or $T_{\max }$, was also a significant factor in determining disease development described by AUDPC. Mature green stems were highly susceptible after wounding, similarly to leaves, but buds and leaf scars expressed the lowest susceptibility. These variations in disease expression according to the tissues will have different impacts on ACC epidemiology.
\end{abstract} LAR), and number of days during the first 2 weeks postinoculation for which the temperature was less than $14^{\circ} \mathrm{C}\left(T_{\min }\right)$ or more than $28^{\circ} \mathrm{C}\left(T_{\max }\right)$ were retained by principal component analysis and canonical correlation
Additional keywords: disease control, environmental effects, modeling

infection on immature fruits can result in cracking and malformations of the fruit, and the presence of canker lesions makes the fruit unacceptable for the fresh market. Heavy infection on fruits and leaves causes premature fruit drop and defoliation.

Variations in the susceptibility of the citrus host occur in relation to tissue age and development cycle of the tree. Susceptibility varies also among citrus species and cultivars and according to the mode of infection and tissue infected $(8,17,18,25,26,32,36)$. Young fruit and leaf tissues are more susceptible than mature tissues, and inoculations that provide direct contact of the bacteria with the mesophyll more often result in lesions. Stomatal structure and density have been shown not to be related to citrus susceptibility (26) even though it has been previously reported (39), Furthermore, symptom expression depends on temperature, which reduces or increases the incubation period (30); the optimum temperature being approximately 28 to $30^{\circ} \mathrm{C}$. Additionally, wounding induced by the larvae of the Asian citrus leaf miner (Phyllocnistis citrella Stainton) increases infection by $X$. axonopodis pv. citri during the flush periods $(10,19)$.

The inoculum density needed for infection varies according to the mode of infection. A concentration of $10^{4}$ to $10^{5} \mathrm{CFU} / \mathrm{ml}$ is required for infection through stomata, while $10^{2} \mathrm{CFU} / \mathrm{ml}$ are efficient for infection process through wounds $(14,61)$. The use of a stomatal inoculation apparatus, which was used to first induce water congestion of tissues followed by inoculation, confirmed that the optimal amount of $X$. axonopodis pv. citri for natural infections on susceptible expanding leaves of grapefruit should approximate $10^{4} \mathrm{CFU} / \mathrm{ml}$, but that infection can also result from single bacterial cells (17).

Once symptoms have developed, bacteria exude from lesions when lesion surfaces are wetted. Higher populations are released from young lesions (54). The pathogen is dispersed by splashing rain and winds in excess of $8.0 \mathrm{~m} \mathrm{~s}^{-1}(21,23,49,50)$.
Publication no. P-2003-0428-03R

This article is in the public domain and not copyrightable. It may be freely reprinted with customary crediting of the source. The American Phytopathological Society, 2003. 
ACC was first reported on Réunion Island in the early 1970s (5), but ACC was probably present long before and was described earlier in the nearby Mascarene Archipelago (59). ACC is now considered to be endemic on the island of Réunion and because of a local request for a diversification of citrus cultivars and the planting of susceptible cultivars, there is a need to control the disease. Réunion Island is a typical tropical island with two seasons. Cool and dry weather prevails from May to September and then temperatures rise until December. Hot and humid weather occurs from January to April and is associated with the passage of hurricanes. Most of the citrus growing areas receive annual rainfalls greater than $1500 \mathrm{~mm}$.

For effective ACC management, a better understanding of disease development and the factors that direct it is necessary. Disease development depends naturally on several different variables involving the host, pathogen, environment, and human activities. These variables, which can be grouped into a set of predictors and a set of potential responses, are often correlated. Such a large set of variables makes analysis difficult. It is necessary to reduce the number of variables to simplify data analysis and interpretation. Principal component analysis (PCA) is a statistical procedure that allows the exploration of the data structure and can address variable reduction and dimensionality. PCA allows the transformation of a set of original variables into a new set of uncorrelated variables, called principal components, which may present more concise information. This technique has been used previously for other pathosystems $(7,40)$. Additionally, one could consider the relationships between these two sets of variables and examine whether combinations of one set of related variables could effectively account for the observed variation in a second set of variables. Canonical correlation analysis (CCA) is a multivariate approach, which can identify environmental variables that highly influence disease expression or disease variables that are highly influenced by the environment. The selected variables could then be used to develop models to explain disease incidence of different parts of the host over the year. This can be achieved by multiple regression analysis (MRA) (6).

By following symptom expression under natural different conditions after repetitive inoculations, we collected a number of outcomes that relate to disease incidence over time and constitute the dependent variables. The highest susceptibility of citrus to ACC is associated with the presence of wounds and young tissues. Mature citrus tissues were wounded to reproduce the effect of piercing, thorn scratches, or other types of wounds. Young tissues were also included to evaluate their susceptibility to disease compared to mature tissues under natural conditions. Another set of host and environmental measurements was collected which represent predictors of disease development and constitute the independent variables. Thus, using ordination by multivariate analysis associated with correlation analysis, we tried to formulate an index of disease that was closely correlated to some combination of independent variables. The objectives of this study were to (i) describe the susceptibility of the different citrus tissues present on the tree to $X$. axonopodis pv. citri throughout the year; (ii) to elucidate the effects of wounding agents on the susceptibility; and (iii) to identify the most meaningful factors which explain ACC disease development.

\section{MATERIALS AND METHODS}

Plot design. Two plots were established in orchards of Tahiti limes (Citrus latifolia) and Pineapple sweet oranges (C. sinensis) located at the CIRAD (International Research Center for Agriculture and Development) experimental research station at SaintPierre, Réunion Island. The sweet orange and lime groves were planted in 1975 (altitude $350 \mathrm{~m}$ ) and 1981 (altitude $150 \mathrm{~m}$ ), respectively, and irrigated by a microjet system and overhead irrigation, respectively. Trees were arranged in a $6 \times 6 \mathrm{~m}$ planting pat- tern. Inoculated trees were randomly selected and separated from each other by at least two noninoculated trees to prevent cross contamination.

Inoculum preparation. Réunion $X$. axonopodis pv. citri strain C40S was used in all inoculations and was selected for its aggressiveness and streptomycin resistance. Strain C40S was previously used in an epidemiological study performed in a simulated nursery on Réunion Island (43), and the estimated daily rates of disease increase were very similar to those calculated for similar experiments conducted in Argentina that utilized a local unmarked $X$. axonopodis pv. citri isolate from grapefruit (23).

Inoculation methods. Inoculum was prepared in sterile distilled water and adjusted turbidometrically to approximately $10^{8} \mathrm{CFU} / \mathrm{ml}$. Four replicates of 12 fruits and 20 leaves were inoculated by spray inoculation on each date. Spray inoculation was accomplished by atomizing the inoculum on leaves and/or fruits until runoff. Five replicates of 10 individuals for each plant organ (leaves, fruits, petioles, buds, and stems) were inoculated by wound inoculation. Needle-prick inoculations were performed on leaves (petioles and laminae), fruits, and buds by stabbing the tissue with a needle. Stems were slashed with a scalpel, and the petioles were broken at their bases to reproduce leaf scars after defoliation. Then, a 10- $\mu \mathrm{l}$ drop of inoculum was deposited on each kind of wound. Inoculations were performed monthly from October 1989 to September 1990.

Rating leaf and fruit age. The age of leaves and fruits was variable at the time of inoculation. The leaf age rating (LAR) relative to maturity was determined from preliminary tests on Pineapple sweet orange leaves following spray and needle-pricking inoculation methods using $\approx 10^{8} \mathrm{CFU} / \mathrm{ml}$ of $X$. axonopodis $\mathrm{pv}$. citri inoculum. LAR was assigned to individual leaves based on their differential responses relative to their susceptibility (internal mesophyll expressed resistance) or their receptivity (external expressed resistance).

LAR corresponded to: 1 = one-third of the maximal size; $2=$ two-thirds of the maximal size; $3=\sim$ maximal size but still soft; 4 = maximal size, just hardened, and dark green; and $5=$ mature leaf, more than 2 months after tissue hardening. A similar approach on fruits of Pineapple sweet orange (which displayed different responses following spray inoculation of a $X$. axonopodis pv. citri inoculum suspension) was used to assign the following fruit age rating (FAR): 1 = young fruit less than 2 months following blossom; 2 = young green fruit in growth phase; $3=$ fruit nearly full size but still green; $4=$ fruit full sized and beginning to turn color; and $5=$ mature, full sized, and colored fruit.

Disease assessments. Disease development resulting from 184 treatments was measured. Treatments consisted of combinations of different factors including the citrus species, type of organ, LAR, FAR, and the date of inoculation (Table 1). Each treatment consisted of four replicates of 12 fruits or 20 leaves (spray inoculation) or five replicates of 10 plant organs (needle-prick inoculation). Disease was assessed every 2 weeks for 84 days following inoculation and expressed as disease incidence.

Statistical analyses. Disease progress curves were developed for each replicate of the different treatments. Data were fitted to nonlinear exponential, logistic, monomolecular, and Gompertz models. The appropriateness of the temporal models was evaluated by the examination of the correlation of observed versus predicted values, examinations of the associated standard residual plots for unique patterns, and for model convergence.

The Gompertz model was later shown to be most appropriate, thus it is necessary to present additional methodology related to the model here. The Gompertz differential equation can be written as $d Y / d t=K Y(-\ln Y)$, and its integrated form, $Y=\exp [-B \exp (-K t)]$, where $d Y / d t=$ daily rate of symptom development, $Y=$ disease incidence, $t=$ time, $K=$ rate parameter, and $B=$ a constant of integration which equals $-\ln \left(Y_{0}\right)(6)$. The $B$ parameter represents the initial amount of disease. 
Using the Gompertz nonlinear model, epidemic variables were calculated based on the specific temporal model parameters for each treatment: $K$ and $B$, the curve inflexion point $(m)$, and the time when $50 \%$ disease incidence was achieved $\left(t_{50}\right)$ (Table 2). For those cases where the Gompertz model did not converge (171 of 872 replicates), the replication was not considered in future analyses except for the MRA discussed below.

Additional descriptive variables included were: area under the disease progress curves (AUDPC); disease incidence after 28 days $\left(Y_{28}\right)$; and final disease incidence $\left(Y_{f}\right)$. Symptoms usually were expressed within 2 or 3 weeks when favorable conditions were met. Two disease incidence variables were retained to evaluate whether the duration of incubation influenced the correlation between incidence and various environmental factors.

Generalized environmental variables were selected that represent those known to impact ACC disease development, Id = inoculation date and LAR/FAR = leaf/fruit age rating (1 to 5). Meteorological data were collected from a weather station located at the CIRAD center in Saint-Pierre. The data taken into account for the variables $R_{n}, T_{\min }, T_{\max }, R H_{80}, R H_{90}$, and $\operatorname{Rad}_{14}$ were for the period of 2 weeks after inoculation, as explained in Table 2 . The limits of temperature were chosen because they approximated the optimal temperature or minimal temperature necessary for infection or bacterial multiplication in planta $(9,30,41)$.

PCA was performed on disease progress curves variables and environmental variables separately by treatment to explore the relationships between variables of the same group and to reduce the redundancy of the original variables to those which were the most descriptive. Selection of principal components and variables were accomplished using the FACTOR procedure of SAS (SAS Institute, Inc., Cary, NC). Principal components or factors are new uncorrelated variables, which are linear combinations of the original variables (28). Each principal component is characterized by a unique eigenvector representing the loadings or contributions of the original variables used to generate the component. Three principal components were generally selected and corresponded to a cumulative eigenvalue cut off always exceeding 0.8 , i.e., more than $80 \%$ of the total variance was explained by the retained principal components for each treatment. Principal components were difficult to interpret directly and therefore, an orthogonal rotation

TABLE 1. Different combinations of factors studied in Asiatic citrus canker disease development observed on Pineapple sweet orange and Tahiti lime at each date of inoculation ${ }^{\mathrm{a}}$

\begin{tabular}{|c|c|c|c|}
\hline \multicolumn{4}{|c|}{ Method of inoculation } \\
\hline \multicolumn{2}{|c|}{ Needle-prick } & \multicolumn{2}{|r|}{ Spray } \\
\hline Plant tissue & Maturity ${ }^{b}$ & Plant tissue & Maturity $^{\mathrm{b}}$ \\
\hline Leaf petioles & $\mathrm{LAR} 5+\mathrm{LAR} \leq 4$ & Leaves & LAR $5+$ LAR $\leq 4$ \\
\hline Leaf laminae & $\mathrm{LAR} 5+\mathrm{LAR} \leq 4$ & Fruits & FAR 1 to 5 \\
\hline Fruits & FAR 1 to 5 & & \\
\hline Stems & Green mature & & \\
\hline Buds & & & \\
\hline Petiole scars & From leaves (LAR 5) & & \\
\hline
\end{tabular}

a Inoculation dates were 4 and 5 October 1989, 2 and 3 November 1989, 30 November and 1 December 1989, 10 and 11 January 1990, 7 and 8 February 1990, 22 and 23 March 1990, 18 and 19 April 1990, 30 and 31 May 1990, 14 and 15 June 1990, 12 and 13 July 1990, 8 and 10 August 1990, and 5 and 7 September 1990 with first and second dates corresponding to inoculation of sweet orange and Tahiti lime, respectively.

${ }^{\mathrm{b}} \mathrm{LAR}=$ leaf age rating where $1=$ one-third of the maximal size; $2=$ two-thirds of the maximal size; $3=\sim$ maximal size but still soft; $4=$ maximal size, just hardened, and dark green; and $5=$ mature leaf, more than 2 months after tissue hardening. Leaves rating LAR 5 were inoculated on all dates. When available, leaves rating LAR 1 to LAR 4 were inoculated. FAR $=$ fruit age rating where $1=$ young fruit less than 2 months following blossom; 2 = young green fruit in growth phase; $3=$ fruit nearly full size but still green; $4=$ fruit full sized and beginning to turn color; and $5=$ mature, full sized, and colored fruit. FAR changed over the date of inoculation. method with the Varimax algorithm (28) was used to provide more interpretable factors by reducing the number of high loadings associated with each factor. This technique identified more meaningful, underlying factors that described the variation in a set of variables.

CCA was performed to extract possible relationships between these two sets of variables, i.e., epidemic versus environmental, via the CANCORR procedure of SAS (SAS Institute, Inc.). A weighted sum, defined as a canonical variate, which reflects the structure of the variables is constructed from linear combination in each set. These two canonical variates correlate maximally with each other. A number of canonical variates are extracted, and each successive canonical variates will explain a unique proportion of variability in the two sets of variables. Canonical variates are uncorrelated with each other and account for less and less variability. The proportion of variance accounted for by the correlation between the respective canonical variates is expressed by their eigenvalues. Each canonical variate can be interpreted by looking at the weights of each set of variables. A large absolute value of this canonical weight indicates a large contribution of the variable to the canonical variate.

MRA was performed to assess the relationship between a dependent variable and a set of independent variables constituted by the reduced number of environmental variables identified by canonical correlation for each treatment. Multiple regression was carried out for each combination inoculation method/plant tissue/species using the maximum $R^{2}$ improvement (MAXR) model selection method. Following this, an attempt was made to select a generalized model to represent each group of similar treatments.

\section{RESULTS}

Description of curves elements. Disease symptoms occurred in almost all the treatments with a large variability among the treatments. However, 11 of 184 treatments did not express any symptoms after 84 days. Spray inoculation was used for eight of these treatments, which involved mature leaves (LAR 5) or mature fruits (FAR 4 or 5) for sweet orange and lime (Fig. 1; Table 3 ). Needle pricking was not conducive to disease for two treat-

TABLE 2. Description of the two sets of variables used to describe Asiatic citrus canker development

\section{Variables}

Epidemic or dependent

$K \quad$ Rate parameter of the Gompertz model (lesion per day)

$B \quad$ Initial amount of disease parameter of the Gompertz model

$m \quad$ Curve inflexion point

$t_{50} \quad$ Time in days when $50 \%$ disease incidence was achieved

AUDPC Area under the disease progress curves

$Y_{28} \quad$ Disease incidence after 28 days

$Y_{f} \quad$ Final disease incidence after 84 days

Environmental or independent

LAR/FAR ${ }^{\mathrm{b}} \quad$ Leaf and fruit age rating

Id Inoculation date

$R_{n} \quad$ Cumulative $\mathrm{cm}$ of rain

$T_{\min } \quad$ Number of days the minimum temperature was less than $14^{\circ} \mathrm{C}$

$T_{\max } \quad$ Number of days the maximum temperature was greater than $28^{\circ} \mathrm{C}$

$\mathrm{RH}_{80} \quad$ Number of days the average relative humidity was less than $80 \%$

$\mathrm{RH}_{90} \quad$ Number of days the average relative humidity was greater than $90 \%$

$\operatorname{Rad}_{14}$ Cumulative radiation (Joules $/ \mathrm{cm}^{2}$ )

a Environmental variables associated with climate are cumulative over the first 2 weeks postinoculation.

b LAR: 1 = one-third of the maximal size; 2 = two-thirds of the maximal size; $3=\sim$ maximal size but still soft; $4=$ maximal size, just hardened, and dark green; and $5=$ mature leaf, more than 2 months after tissue hardening. FAR: 1 = young fruit less than 2 months following blossom; 2 = young green fruit in growth phase; $3=$ fruit nearly full size but still green; $4=$ fruit full sized and beginning to turn color; and $5=$ mature, full sized, and colored fruit. 
ments of mature fruits and one treatment of leaf scars. However, 16 treatments expressed $100 \%$ disease incidence after 84 days, with 15 of these resulting from the wound inoculation method on leaves whatever the maturity or on young fruits as shown in the disease expression curves (Fig. 1). The spray treatment, which gave this incidence of $100 \%$ was on young fruits.

The Gompertz model was the most appropriate to describe disease progress models evaluated (exponential, monomolecular,
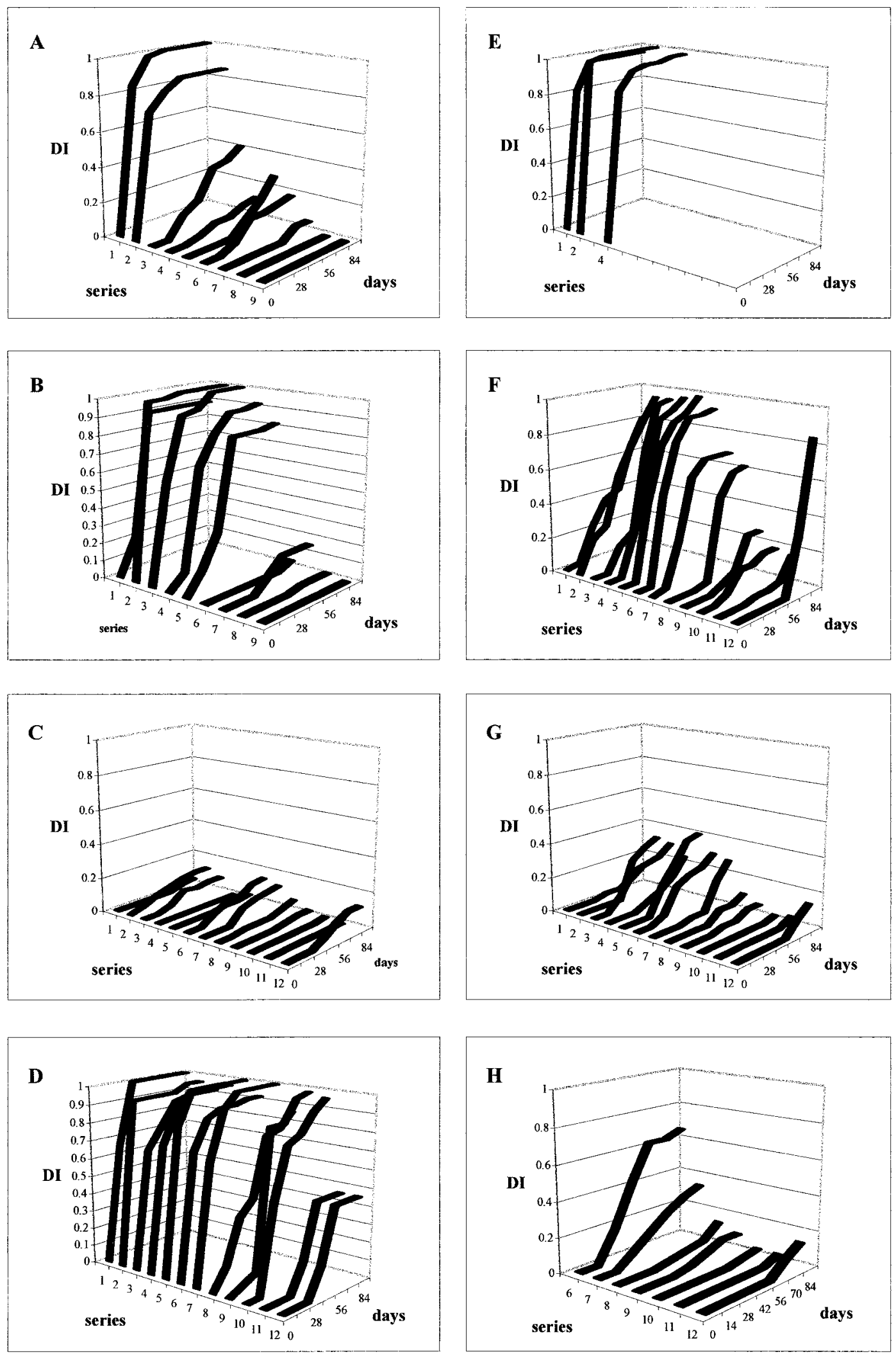

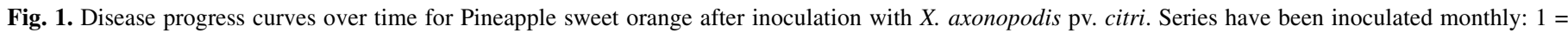
4 October 1989; 2 = 2 November; 3 = 30 November; $4=10$ January 1990; $5=07$ February; $6=22$ March; $7=18$ April; $8=30$ May; $9=14$ June; $10=12$ July; $11=8$ August; and $12=05$ September. A, fruits after spray inoculation, $\mathbf{B}$, fruits after needle-prick inoculation, $\mathbf{C}$, mature leaves after spray inoculation, $\mathbf{D}$, mature leaf laminae after needle-prick inoculation, E, young leaf laminae after needle-prick inoculation, $\mathbf{F}$, green mature stems after needle-prick inoculation, $\mathbf{G}$, leaf scars, and $\mathbf{H}$, buds after needle-prick inoculation. 
logistic, and Gompertz). Of 872 replicates, 137 did not develop any disease (Table 4). Of 735 temporal disease progress curves analyzed, 400 were best described by the Gompertz model, 153 by the logistic model, 153 by the monomolecular model, and 29 by the exponential model (Table 4). However, for many of the disease progress curves better described by another model, the Gompertz model still provided an acceptable description and therefore, the variables associated with the Gompertz model were used for all further analyses. For 171 replicates, the Gompertz model did not converge even after using different values, and thus, these curves were no longer analyzed for model parameters. The important features of this model were not sufficiently covered by the range of $x$ values of time. For 41 of these 171 curves, this was due to the curve being defined by only two points, that is, $100 \%$ disease incidence occurred during the second observation. For the other curves for which the Gompertz model did not converge, two situations were observed. Firstly, the disease development lagged (remained relatively constant and low in incidence) and then jumped to a relatively high incidence only at the last date of observation. For instance, leaves and fruits with an age rating greater than 3 which received a spray treatment, or the petiole scars belonged to this type. For the second situation, the disease exploded, reaching nearly $100 \%$ incidence after 28 or 42 days and then remained at this asymptope. This situation was observed for 80 curves and especially for the leaves of various ages, which were wound inoculated except for those inoculated between the end of May and July.

The range of disease incidence observed 84 days after inoculation of mature leaves for Pineapple sweet oranges was 0 to 0.15 and 0.46 to 1.0 for the spray and the needle-prick methods of inoculation, respectively (Table 3 ). For the Tahiti lime, the range of disease incidence was 0 to 0.325 and 0.10 to 1.0 , respectively, for the spray and the needle-prick methods of inoculation. Disease incidence of young leaves (LAR 1 to 4 ) of both citrus species ranged from 0.05 to 0.98 and from 0.88 to 1 after spray and needle-prick inoculation, respectively. The disease incidence observed on fully expanded green stems after wound inoculation varied from 0.16 to 0.98 and from 0.30 to 0.98 for Pineapple sweet oranges and Tahiti lime, respectively. On fruits, disease incidence varied according to the fruit age, resulting in no symptoms on mature fruits to nearly an incidence of 1.0 on young fruits of both species, irrespective of the method of inoculation (Table 3 ). To describe these variations of the disease progress curves at the treatment level, disease progress curves were fitted to the models as previously described. The Gompertz model was still the most appropriate (data not shown). The AUDPC values and the Gompertz rate parameter $K$ estimated from the mean values were also higher following wound inoculation or on young tissues (Table 3). However, a close range of $K$ values could have been sometimes estimated while the range of disease incidence or AUDPC values was more variable as shown for buds. $t_{50}$ varied greatly among the different treatments (Table 3). For instance, maximum values of $t_{50}$ obtained for young leaves were similar to the minimum values relative to mature leaves.

Description and selection of environmental variables. Inspection of the correlation matrix of the environmental variables revealed high correlations among the variables FAR and $I d$ for all the fruit treatments regardless of the method of inoculation. The associated correlation coefficients were greater than 0.9 and $\approx 0.75$ for sweet oranges and Tahiti limes, respectively. This was expected because the maturity of the fruits increased with later dates of inoculation. Other correlations were observed among a few variables, especially between $T_{\max }$ and $T_{\min }$, but they were not consistent among all the different treatments. For the majority of treatments, three principal components were most often determined by PCA which explained more than $80 \%$ of the total variation in the data as shown for the fruits and leaves of the Pineapple sweet orange (Table 5). For a few treatments, only two factors were required to explain a similar proportion of the variation. An orthogonal rotation technique was applied to these

TABLE 3. Range of epidemic variables describing Asiatic citrus canker disease development for all dates of inoculation calculated at the treatment level

\begin{tabular}{|c|c|c|c|c|c|c|}
\hline \multirow[b]{2}{*}{ Factors } & \multicolumn{2}{|c|}{ Disease incidence } & \multicolumn{2}{|c|}{ Gompertz parameters $^{\mathrm{a}}$} & \multirow[b]{2}{*}{ AUDPC $^{b}$} & \multirow[b]{2}{*}{$t_{50}$} \\
\hline & 28 days & 84 days & $K$ & $B$ & & \\
\hline \multicolumn{7}{|l|}{ Spray inoculation } \\
\hline Sweet orange $\mathrm{LAR}^{\mathrm{c}} 5$ leaves & $0-0.062$ & $0-0.15$ & $0.05-0.051$ & $107.1-314.1$ & $0-6.12$ & $101.0-120.0$ \\
\hline Lime LAR 5 leaves & $0-0.05$ & $0-0.32$ & $0.049-0.051$ & $51.9-315.8$ & $0-6.47$ & $91.8-120.2$ \\
\hline Sweet orange LAR 1 to 4 leaves & $0-0.32$ & $0.05-0.5$ & $0.04-0.05$ & $13.9-206.9$ & $0.7-26.7$ & $64.9-112.8$ \\
\hline Lime LAR 2 to 3 leaves & $0.01-0.9$ & $0.23-0.98$ & $0.04-0.34$ & $10.5-89.9$ & $8.1-66.1$ & $14.1-94.8$ \\
\hline Sweet orange FAR ${ }^{\mathrm{d}} 1$ to 5 fruits & $0-0.98$ & $0-1$ & $0.04-0.44$ & $16.0-178.6$ & $0-73.9$ & $11.0-110.8$ \\
\hline Lime FAR 1 to 5 fruits & $0-0.69$ & $0-0.81$ & $0.04-0.13$ & $8.5-277.2$ & $0-50.3$ & $22.3-117.7$ \\
\hline \multicolumn{7}{|l|}{ Needle-prick inoculation } \\
\hline Sweet orange LAR 5 petioles & $0-1$ & $0.48-1$ & $0.047-0.64$ & $9.45-616$ & 21.0-74.9 & $8.5-65.4$ \\
\hline Sweet orange LAR 5 laminae & $0-1$ & $0.46-1$ & $0.047-0.60$ & $10-441$ & $18.3-71.9$ & $10.4-68.2$ \\
\hline Lime LAR 5 petioles & $0-0.92$ & $0.52-1$ & $0.048-0.36$ & $10-309$ & $7.8-68.7$ & $10.7-79.3$ \\
\hline Lime LAR 5 laminae & $0-0.96$ & $0.1-0.98$ & $0.049-0.49$ & $9-405.9$ & $3.3-72.5$ & $11.0-106.4$ \\
\hline Sweet orange LAR 1 to 4 petioles & $0.96-1$ & $0.96-1$ & $0.46-0.90$ & $66-300$ & $72.6-76.5$ & $6.7-9.9$ \\
\hline Sweet orange LAR 1 to 4 laminae & $0.94-1$ & $0.96-1$ & $0.38-0.64$ & $48-110$ & $71.2-76.2$ & $8.5-11.0$ \\
\hline Lime LAR 3 petioles & 0.84 & 0.88 & 0.49 & 209 & 67.4 & 11.5 \\
\hline Lime LAR 3 laminae & 0.88 & 0.9 & 0.29 & 17 & 64.3 & 11.1 \\
\hline Sweet orange FAR 1 to 5 fruits & $0-0.98$ & $0-1$ & $0.049-0.64$ & $14-281$ & $0-75.9$ & $8.5-117.7$ \\
\hline Lime FAR 1 to 5 fruits & $0-0.52$ & $0-0.82$ & 0.043-0.09 & $15-281$ & $0-45.9$ & $32.9-118.4$ \\
\hline Sweet orange stems & $0-0.5$ & $0.16-0.98$ & $0.047-0.14$ & $11-103$ & $2.2-49.5$ & 29.0-103.4 \\
\hline Lime stems & $0-0.86$ & $0.3-0.98$ & $0.040-0.24$ & $9-158$ & $7.7-57.6$ & $16.7-84.2$ \\
\hline Sweet orange buds & $0-0.18$ & $0.04-0.66$ & $0.045-0.052$ & $15-229$ & $0.3-30.3$ & $58.9-114.4$ \\
\hline Lime buds & $0-0.2$ & $0.06-0.58$ & $0.045-0.051$ & $14.5-196.5$ & $1.2-24.1$ & $65.3-111.1$ \\
\hline Sweet orange leaf scars & $0-0.08$ & $0.02-0.32$ & $0.043-0.051$ & $16-291$ & $0.1-12.4$ & 73.3-117.9 \\
\hline Lime leaf scars & $0-0.12$ & $0-0.58$ & $0.046-0.051$ & $16-281.3$ & $0-22.5$ & $65.7-108.7$ \\
\hline
\end{tabular}

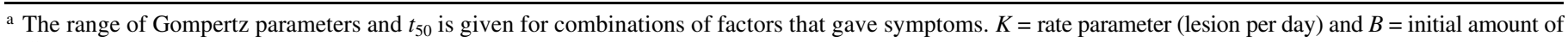
disease parameter.

b AUDPC = area under the disease progress curves.

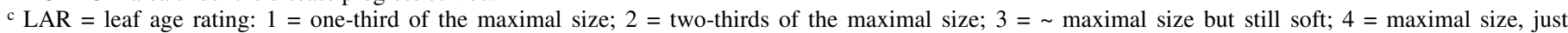
hardened, and dark green; and 5 = mature leaf, more than 2 months after tissue hardening.

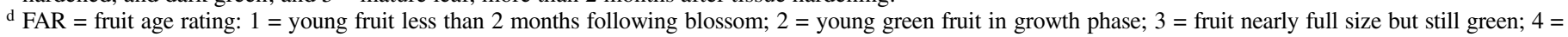
fruit full sized and beginning to turn color; and $5=$ mature, full sized, and colored fruit. 
principal components to improve their meaningfulness. The observation of the factor loadings of the different variables on the principal components showed that all of the variables were required to explain the majority of the variance within each treatment with the exception of $R A D_{14}$ (Table 5). This variable was not considered further. Considering the loadings of each variable on the initial factors and the methods of inoculation, which are known to require different conditions for successful infection in the case of foliar bacteria, variables were divided into two subsets according to the method of inoculation. The subset for the treatments associated with the wound inoculation method included $I d$, LAR, FAR, $T_{\min }$, and $T_{\max }$. The subset associated with spray inoculation included $I d$, LAR, FAR, $R_{n}, T_{\min }, T_{\max }$, and $R H_{90}$.
Description and selection of epidemic variables. High correlations were observed among the epidemic variables, and the correlations were consistent among the different treatments. High correlations occurred between AUDPC and all other epidemic variables except for the Gompertz curve parameters $K$ and $B$, which did not show any noticeable correlations with other variables. More than $85 \%$ of the total variation was explained by two or three principal components as shown for the plant tissues of Pineapple sweet orange (Table 6). While AUDPC, $Y_{28}, Y_{f}, t_{50}$, and $m$ presented a high loading for the same factor, variables $K$ and $B$ represented the main loadings for a single principal component for most of the treatments of both citrus species (Table 6). Therefore, AUDPC, $K$ and $B$ were retained as epidemic variables for further investigation.

TABLE 4. Evaluation of nonlinear models to describe Asiatic citrus canker disease expression on Pineapple sweet orange and Tahiti lime over time

\begin{tabular}{|c|c|c|c|c|c|c|}
\hline \multirow[b]{2}{*}{ Treatments $^{\mathrm{a}}$} & \multirow[b]{2}{*}{ Number of replicate curves ${ }^{b}$} & \multicolumn{4}{|c|}{ Most appropriate model } & \multirow[b]{2}{*}{ Replicates with no disease expression ${ }^{c}$} \\
\hline & & Logistic & Gompertz & Monomolecular & $\overline{\text { Exponential }}$ & \\
\hline \multicolumn{7}{|c|}{ Spray inoculation } \\
\hline Young leaves & 20 & 3 & 10 & 6 & 0 & 1 \\
\hline Mature leaves & 96 & 0 & 29 & 20 & 8 & 39 \\
\hline Fruits & 76 & 7 & 28 & 19 & 0 & 22 \\
\hline \multicolumn{7}{|l|}{ Needle-pricking } \\
\hline \multicolumn{7}{|l|}{ Young leaves } \\
\hline Petioles & 20 & 1 & 12 & 7 & 0 & 0 \\
\hline Laminae & 20 & 8 & 7 & 5 & 0 & 0 \\
\hline \multicolumn{7}{|l|}{ Mature leaves } \\
\hline Petioles & 120 & 40 & 65 & 15 & 0 & 0 \\
\hline Laminae & 120 & 53 & 46 & 19 & 0 & 2 \\
\hline Fruits & 90 & 10 & 32 & 20 & 2 & 26 \\
\hline Stems & 120 & 27 & 78 & 9 & 5 & 1 \\
\hline Buds & 70 & 2 & 32 & 14 & 6 & 16 \\
\hline Petiole cuts & 120 & 2 & 61 & 19 & 8 & 30 \\
\hline Total & 872 & $15 \overline{3}$ & 400 & 153 & 29 & 137 \\
\hline
\end{tabular}

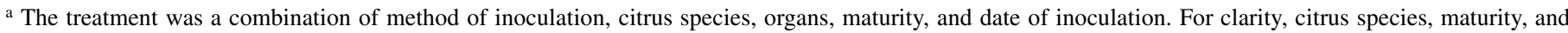
date of inoculation are not indicated here. Young leaves include LAR 1 to 4, mature leaves correspond to LAR 5. Fruits are composed of FAR 1 (young fruit less than 2 months following blossom) to 5 (to mature, full sized, and colored fruit).

${ }^{b}$ Spray inoculation $=4$ replicates per treatment. Needle-pricking inoculation $=5$ replicates per treatment.

c No symptom appeared 84 days after inoculation.

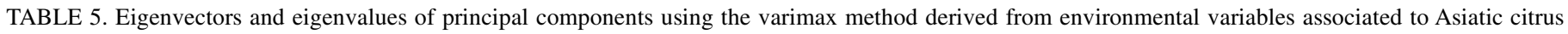
canker development on fruits and leaves of Pineapple sweet orange

\begin{tabular}{|c|c|c|c|c|c|c|c|c|c|c|}
\hline \multirow[b]{2}{*}{ Treatment } & \multirow{2}{*}{$\begin{array}{c}\text { Principal } \\
\text { component }\end{array}$} & \multirow{2}{*}{$\begin{array}{l}\text { Cumulative } \\
\text { eigenvalues }\end{array}$} & \multicolumn{8}{|c|}{ Environmental variables ${ }^{\mathrm{a}}$} \\
\hline & & & $I d$ & LAR/FAR & $R_{n}$ & $T_{\max }$ & $T_{\min }$ & $\mathrm{RH}_{80}$ & $\mathrm{RH}_{90}$ & $R A D_{14}$ \\
\hline \multicolumn{11}{|l|}{ Spray } \\
\hline \multirow[t]{3}{*}{ Sweet orange leaves } & 1 & 0.44 & -0.39 & 0.03 & 0.15 & $0.94 * \mathrm{~b}$ & $-0.97 *$ & -0.28 & -0.34 & 0.62 \\
\hline & 2 & 0.72 & $0.84 *$ & $0.74 *$ & 0.08 & 0.02 & -0.05 & $-0.87 *$ & 0.43 & -0.38 \\
\hline & 3 & 0.86 & 0.04 & 0.17 & $0.95^{*}$ & -0.1 & -0.1 & -0.24 & $0.78 *$ & -0.54 \\
\hline \multirow[t]{3}{*}{ Sweet orange fruits } & 1 & 0.56 & $0.98 *$ & $0.96^{*}$ & 0.25 & -0.06 & 0.09 & $-0.77 *$ & $0.71 *$ & $-0.77 *$ \\
\hline & 2 & 0.84 & 0.01 & 0.11 & 0.02 & $-0.92 *$ & $0.97 *$ & 0.52 & 0.33 & -0.46 \\
\hline & 3 & 0.95 & 0.14 & 0.18 & $0.96^{*}$ & -0.17 & -0.03 & -0.23 & 0.58 & -0.25 \\
\hline \multicolumn{11}{|l|}{ Wounding } \\
\hline \multirow[t]{3}{*}{ Sweet orange leaf laminae } & 1 & 0.43 & 0.42 & -0.10 & -0.14 & $-0.91 *$ & $0.97 *$ & 0.25 & 0.36 & -0.63 \\
\hline & 2 & 0.72 & $0.84 *$ & $0.78 *$ & 0.06 & 0.12 & -0.03 & $-0.83 *$ & 0.44 & -0.37 \\
\hline & 3 & 0.86 & 0.08 & 0.10 & $0.95^{*}$ & -0.10 & -0.10 & -0.28 & $0.77 *$ & -0.54 \\
\hline \multirow[t]{3}{*}{ Sweet orange leaf petioles } & 1 & 0.43 & 0.42 & -0.10 & -0.14 & $-0.91 *$ & $0.97 *$ & 0.25 & 0.36 & -0.63 \\
\hline & 2 & 0.72 & $0.84 *$ & $0.78 *$ & 0.06 & 0.12 & -0.03 & $-0.83 *$ & 0.44 & -0.37 \\
\hline & 3 & 0.86 & 0.08 & 0.10 & $0.95^{*}$ & -0.10 & -0.10 & -0.28 & $0.77 *$ & -0.54 \\
\hline \multirow[t]{3}{*}{ Sweet orange fruits } & 1 & 0.55 & $0.97 *$ & $0.98 *$ & 0.22 & -0.04 & 0.07 & $-0.77 *$ & 0.69 & $-0.76^{*}$ \\
\hline & 2 & 0.84 & 0.02 & 0.05 & 0.02 & $-0.92 *$ & $0.97 *$ & 0.50 & 0.35 & -0.47 \\
\hline & 3 & 0.94 & 0.17 & 0.11 & $0.96^{*}$ & -0.18 & 0.03 & -0.26 & 0.59 & -0.27 \\
\hline
\end{tabular}

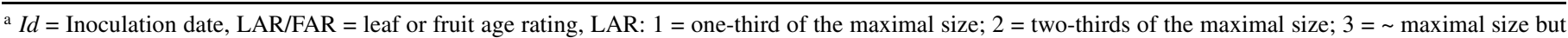
still soft; 4 = maximal size, just hardened, and dark green; and 5 = mature leaf, more than 2 months after tissue hardening. FAR: $1=$ young fruit less than 2 months following blossom; 2 = young green fruit in growth phase; 3 = fruit nearly full size but still green; 4 = fruit full sized and beginning to turn color; and $5=$ mature, full sized, and colored fruit, $R_{n}=$ cumulative $\mathrm{cm}$ of rain for the period of 2 weeks postinoculation, $T_{\text {min }}=$ number of days during the first 2 weeks postinoculation for which the minimun temperature was less than $14^{\circ} \mathrm{C}, T_{\max }=$ number of days during the first 2 weeks postinoculation for which the maximum temperature was greater than $28^{\circ} \mathrm{C}, \mathrm{RH}_{80}=$ number of days during the first 2 weeks postinoculation for which the average relative humidity was less than $80 \%, R H_{90}=$ number of days during the first 2 weeks postinoculation for which the average relative humidity was greater than $90 \%$, $R a d_{14}=$ cumulative radiation (Joules $/ \mathrm{cm}^{2}$ ) for 14 days following inoculation.

$\mathrm{b} *$ indicates loading values of variables $>0.7$ for the principal components. 
Relationships between epidemic and environmental variables. Three canonical variables were suggested by the program due to the minimum number of epidemic variables. The canonical correlation analysis between epidemic variables and environmental variables associated with the spray treatment resulted in high coefficients of canonical correlation (0.820 to 0.965$)$ for the first canonical variable (Table 7). Greater eigenvalues for this canonical variable indicated that it accounted for the majority of variability between the correlations of the three canonical variables. Furthermore, only the first canonical variable was highly statistically significant $(P>F=0.0001)$ for these treatments, whereas the two other canonical variables showed weak or no significance.
The inspection of the canonical structure showed that for the epidemic variables, the first canonical variate of the environmental variables was highly correlated with AUDPC (|canonical weights| greater than 0.73) (Table 8). For the set of environmental variables, LAR and FAR were highly correlated with canonical variate 1 (|canonical weights| greater than 0.73 ) for the spray treatments. The variable $I d$ showed moderate to weak correlation with canonical variate 1 for fruits and leaves, respectively. $T_{\max }, T_{\min }$, and $R_{n}$ were also weakly correlated to this canonical variate.

The canonical correlation values, eigenvalues, and the significance of canonical variates between the epidemic variables and

TABLE 6. Eigenvectors and eigenvalues of principal components using the varimax method derived from epidemic variables associated to Asiatic citrus canker development on different plant tissues of Pineapple sweet orange

\begin{tabular}{|c|c|c|c|c|c|c|c|c|c|}
\hline \multirow[b]{2}{*}{ Treatment } & \multirow{2}{*}{$\begin{array}{l}\text { Principal } \\
\text { component }\end{array}$} & \multirow{2}{*}{$\begin{array}{l}\text { Cumulative } \\
\text { eigenvalues }\end{array}$} & \multicolumn{7}{|c|}{ Epidemic variables $^{\mathrm{a}}$} \\
\hline & & & $Y_{28}$ & $Y_{f}$ & $K$ & $B$ & $t_{50}$ & $m$ & AUDPC \\
\hline \multicolumn{10}{|l|}{ Spray } \\
\hline Sweet orange leaves & 1 & 0.64 & $0.89 * \mathrm{~b}$ & $0.85^{*}$ & 0.02 & -0.74 & -0.4 & -0.48 & $0.92 *$ \\
\hline \multirow[t]{3}{*}{ Sweet orange fruits } & 1 & 0.66 & $0.95^{*}$ & $0.98^{*}$ & -0.04 & -0.13 & $-0.89^{*}$ & $-0.9^{*}$ & $0.97 *$ \\
\hline & 2 & 0.87 & 0.12 & -0.04 & $0.98^{*}$ & -0.07 & 0.43 & 0.41 & 0.09 \\
\hline & 3 & 0.98 & -0.18 & -0.07 & -0.08 & $0.98^{*}$ & -0.04 & 0.01 & -0.19 \\
\hline \multirow[t]{2}{*}{ Sweet orange leaf petioles } & 1 & 0.68 & $0.83 *$ & $0.86^{*}$ & $0.7 *$ & -0.03 & $-0.97 *$ & $-0.97 *$ & $0.98 *$ \\
\hline & 2 & 0.87 & -0.38 & 0.23 & 0.46 & $0.95^{*}$ & -0.01 & 0.03 & -0.02 \\
\hline \multirow[t]{2}{*}{ Sweet orange fruits } & 1 & 0.75 & $0.91^{*}$ & $0.95^{*}$ & 0.69 & 0.06 & $-0.95^{*}$ & $-0.95^{*}$ & $0.91 *$ \\
\hline & 2 & 0.9 & 0.04 & 0.19 & 0.56 & $0.97 *$ & -0.15 & -0.12 & 0.19 \\
\hline \multirow[t]{2}{*}{ Sweet orange buds } & 1 & 0.71 & $0.78^{*}$ & $0.98^{*}$ & 0.68 & -0.31 & $-0.97 *$ & $-0.98^{*}$ & $0.96^{*}$ \\
\hline & 2 & 0.92 & -0.27 & -0.07 & 0.69 & $0.92 *$ & -0.14 & -0.01 & -0.23 \\
\hline Sweet orange petiole cuts & 3 & 0.89 & -0.28 & -0.06 & $0.88 *$ & -0.35 & 0.5 & 0.45 & 0.04 \\
\hline
\end{tabular}

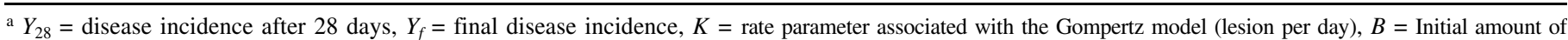
disease parameter associated with the Gompertz model, $t_{50}=$ time in days when 0.50 disease incidence was achieved, $m=$ curve inflexion point, and AUDPC $=$ area under the disease progress curves (\% days).

$\mathrm{b} *$ indicates loading values of variables $>0.7$ for the principal components.

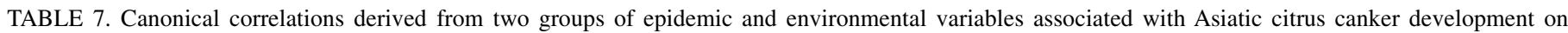
Pineapple sweet orange (PSO) and Tahiti lime (TL)

\begin{tabular}{|c|c|c|c|c|c|c|c|}
\hline \multirow[b]{2}{*}{ Inoculation method of plant tissue } & \multirow[b]{2}{*}{ Canonical variate } & \multicolumn{2}{|c|}{ Canonical correlation } & \multicolumn{2}{|c|}{ Eigenvalue } & \multicolumn{2}{|c|}{$P>F^{\mathrm{a}}$} \\
\hline & & PSO & $\mathrm{TL}$ & PSO & $\mathrm{TL}$ & PSO & $\mathrm{TL}$ \\
\hline \multirow[t]{3}{*}{ Spray leaves } & 1 & 0.82 & 0.96 & 2.05 & 13.38 & 0.0001 & 0.0001 \\
\hline & 2 & 0.51 & 0.50 & 0.36 & 0.34 & 0.11 & 0.06 \\
\hline & 3 & 0.20 & 0.37 & 0.04 & 0.16 & 0.76 & 0.21 \\
\hline \multirow[t]{3}{*}{ Spray fruits } & 1 & 0.95 & 0.95 & 10.11 & 9.57 & 0.0001 & 0.0001 \\
\hline & 2 & 0.67 & 0.41 & 0.82 & 0.20 & 0.11 & 0.78 \\
\hline & 3 & 0.21 & 0.24 & 0.05 & 0.06 & 0.88 & 0.80 \\
\hline \multirow[t]{3}{*}{ Wounding leaf laminae } & 1 & 0.82 & 0.82 & 2.03 & 2.12 & 0.0001 & 0.0001 \\
\hline & 2 & 0.37 & 0.45 & 0.16 & 0.26 & 0.48 & 0.08 \\
\hline & 3 & 0.04 & 0.09 & 0.001 & 0.01 & 0.97 & 0.82 \\
\hline \multirow[t]{3}{*}{ Wounding leaf petioles } & 1 & 0.81 & 0.83 & 1.99 & 2.29 & 0.0015 & 0.0001 \\
\hline & 2 & 0.47 & 0.34 & 0.29 & 0.13 & 0.35 & 0.41 \\
\hline & 3 & 0.17 & 0.09 & 0.03 & 0.01 & 0.69 & 0.80 \\
\hline \multirow[t]{3}{*}{ Wounding fruits } & 1 & 0.92 & 0.87 & 5.81 & 3.11 & 0.0001 & 0.0001 \\
\hline & 2 & 0.31 & 0.33 & 0.11 & 0.12 & 0.73 & 0.46 \\
\hline & 3 & 0.13 & 0.21 & 0.02 & 0.04 & 0.77 & 0.45 \\
\hline \multirow[t]{3}{*}{ Wounding stems } & 1 & 0.87 & 0.70 & 3.26 & 0.99 & 0.0001 & 0.0001 \\
\hline & 2 & 0.17 & 0.28 & 0.03 & 0.08 & 0.77 & 0.31 \\
\hline & 3 & 0.06 & 0.11 & 0.004 & 0.01 & 0.64 & 0.44 \\
\hline \multirow[t]{3}{*}{ Wounding buds } & 1 & 0.93 & 0.88 & 6.67 & 3.63 & 0.0001 & 0.0001 \\
\hline & 2 & 0.42 & 0.38 & 0.21 & 0.17 & 0.13 & 0.33 \\
\hline & 3 & 0.29 & 0.05 & 0.09 & 0.002 & 0.14 & 0.78 \\
\hline \multirow[t]{3}{*}{ Wounding leaf scars } & 1 & 0.73 & 0.69 & 1.19 & 0.92 & 0.0001 & 0.0001 \\
\hline & 2 & 0.49 & 0.33 & 0.32 & 0.12 & 0.005 & 0.12 \\
\hline & 3 & 0.20 & 0.17 & 0.04 & 0.03 & 0.17 & 0.22 \\
\hline
\end{tabular}

a Test for significance of canonical correlation where probability is associated to the null hypothesis. 
the environmental variables associated with wounding treatments indicated that the first canonical variate was capable of explaining the majority of the variability between these two sets of variables (Table 7). Inspection of the canonical structure for the epidemic variables revealed that AUDPC was always highly correlated with canonical variate 1 (|canonical weights| greater than 0.68 ). For a few treatments, $K$ and $B$ were moderately correlated with canonical variate 1 , as shown for $K$ on leaves and fruits of Pineapple sweet orange (Table 8). For the environmental variables, the weight of $I d$ on canonical variate 1 of the epidemic variables was commonly moderate to high except for one treatment, i.e., leaf scars of Tahiti lime (Table 8). A variable describing the tissue age was not used for all the treatments because for some plant organs, the age of tissues was similar at all the inoculation dates. Therefore, when a variable relating to the age of tissues was appropriate, it was the highest correlated variable with the first canonical variate for the fruit treatment regardless of the species (|canonical weights $\mid$ greater than 0.80 ) but was weakly correlated for the leaf treatment $(0.24<\mid$ canonical weights $\mid<0.38) . T_{\min }$ and $T_{\max }$ showed moderate to high correlations with the first canonical variate and their |canonical weights| ranges were 0.36 to 0.89 and 0.29 to 0.92 , respectively (Table 8). This was consistent among all the treatments except the fruit treatment on Tahiti lime.

Multiple regression model. Following CCA, AUDPC was always highly correlated with the first canonical variate, which explained most of the variability between the two sets of variables and was then retained as the strongest epidemic dependent variable. Combinations of LAR and FAR, $I d, T_{\min }$ and $T_{\max }$ were used as independent variables needed to describe the environmental influences in the MRA. The appropriateness of the models was determined for each different treatment based on the obser- vations of $R^{2}$ (Table 9). For the spray treatments, variables LAR/ FAR, $T_{\min }$, and $T_{\max }$ were consistently associated with the most appropriate models. Two models were slightly improved when Id was utilized. Therefore, variables LAR/FAR, $T_{\min }$, and $T_{\max }$ were retained to develop a generalized model to describe AUDPC when inoculum was applied via spray rather than wounding (Table 9). All the variables retained by the MRA showed a significant to highly significant $t$ test for the estimated parameters except for one variable for which $P<0.10$ (Table 9).

For the treatments with wounding inoculation, the combinations of variables which gave rise to the most superior models were different among the treatments (Table 9). A unique combination of environmental variables was selected which gave the best generalized model for each different organ. $I d$ and $T_{\min }$ gave rise to the best descriptive model for disease expression on leaves, whereas, FAR and $T_{\min }$ were the most appropriate variables for disease expression on fruits. Variables $I d$ and $T_{\max }$ in combination and variable $T_{\max }$ alone were the most appropriate variables, respectively, for models to describe disease expression on stems and buds. Each predictor variable retained for these plant tissues was significant except for the petiole cut of Tahiti lime (Table 9). No common variables were found to describe a generalized model for disease resulting from petiole cuts.

\section{DISCUSSION}

In the tropics, moisture is not a limiting factor and is usually present daily in some form. Therefore, the quantity of rain and relative humidity had little effect on disease development and expression. This omnipresent moisture provides a very conducive environment and constitutes one of the bacteria's most immediate

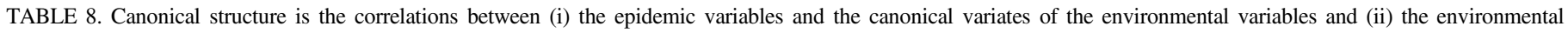
variables and the canonical variates of the epidemic variables describing Asiatic citrus canker disease expression on Pineapple sweet orange (PSO) and Tahiti lime (TL)

\begin{tabular}{|c|c|c|c|c|c|c|c|c|c|c|c|c|c|c|c|c|c|c|c|}
\hline \multirow{3}{*}{$\begin{array}{l}\text { Inoculation of } \\
\text { plant tissue }\end{array}$} & \multirow[b]{3}{*}{$\mathrm{CV}^{\mathrm{c}}$} & \multicolumn{6}{|c|}{ Epidemic variables $^{\mathrm{a}}$} & \multicolumn{12}{|c|}{ Environmental variables ${ }^{\mathrm{b}}$} \\
\hline & & \multicolumn{2}{|c|}{$K$} & \multicolumn{2}{|c|}{$B$} & \multicolumn{2}{|c|}{ AUDPC } & \multicolumn{2}{|c|}{$I d$} & \multicolumn{2}{|c|}{ Age rating } & \multicolumn{2}{|c|}{$R_{n}$} & \multicolumn{2}{|c|}{$T_{\min }$} & \multicolumn{2}{|c|}{$T_{\max }$} & \multicolumn{2}{|c|}{$R H_{90}$} \\
\hline & & PSO & TL & PSO & $\mathrm{TL}$ & PSO & $\mathrm{TL}$ & PSO & $\mathrm{TL}$ & PSO & $\mathrm{TL}$ & PSO & $\mathrm{TL}$ & PSO & TL & PSO & $\mathrm{TL}$ & PSO & TL \\
\hline \multirow[t]{3}{*}{ Spray leaves } & 1 & 0.29 & 0.02 & 0.19 & 0.25 & -0.73 & -0.95 & 0.28 & 0.32 & 0.78 & 0.95 & 0.24 & -0.12 & -0.34 & -0.01 & 0.24 & 0.13 & 0.19 & 0.06 \\
\hline & 2 & -0.44 & 0.50 & 0.47 & -0.20 & -0.23 & 0.03 & 0.32 & -0.33 & 0.05 & 0.01 & -0.01 & -0.10 & 0.32 & 0.09 & -0.16 & -0.16 & 0.27 & -0.30 \\
\hline & 3 & 0.07 & 0.01 & -0.23 & 0.32 & -0.01 & 0.05 & 0.05 & -0.05 & 0.03 & 0.01 & -0.01 & 0.26 & 0.03 & -0.22 & -0.07 & 0.29 & 0.08 & 0.19 \\
\hline \multirow[t]{3}{*}{ Spray fruits } & 1 & 0.21 & -0.01 & -0.33 & -0.15 & 0.94 & -0.94 & -0.72 & 0.56 & -0.73 & 0.89 & -0.20 & -0.37 & -0.21 & 0.26 & -0.18 & -0.13 & -0.48 & 0.11 \\
\hline & 2 & -0.44 & -0.25 & 0.55 & 0.29 & -0.03 & 0.04 & 0.21 & 0.03 & 0.28 & 0.10 & 0.39 & 0.04 & -0.34 & 0.07 & -0.49 & -0.22 & 0.38 & -0.04 \\
\hline & 3 & 0.07 & -0.19 & 0.09 & -0.16 & -0.02 & 0.01 & 0.05 & -0.01 & 0.02 & -0.01 & -0.01 & 0.09 & -0.03 & 0.05 & -0.03 & -0.01 & 0.01 & 0.13 \\
\hline Wounding & 1 & -0.50 & -0.06 & 0.11 & -0.23 & -0.81 & 0.81 & 0.74 & -0.70 & 0.24 & -0.27 & & & 0.72 & -0.46 & -0.66 & 0.49 & & \\
\hline \multirow[t]{2}{*}{ leaf laminae } & 2 & -0.28 & -0.29 & -0.11 & 0.36 & -0.03 & -0.04 & 0.04 & 0.14 & 0.03 & 0.08 & $\mathrm{NI}^{\mathrm{d}}$ & NI & -0.04 & 0.28 & 0.17 & -0.06 & NI & NI \\
\hline & 3 & 0.01 & 0.07 & 0.03 & 0.05 & 0.01 & 0.01 & 0.01 & -0.01 & 0.02 & -0.08 & & & -0.01 & 0.04 & 0.01 & -0.05 & & \\
\hline Wounding & 1 & -0.66 & 0.59 & 0.05 & -0.28 & -0.80 & 0.82 & 0.78 & -0.63 & 0.36 & -0.38 & & & 0.57 & -0.54 & -0.46 & 0.58 & & \\
\hline \multirow[t]{2}{*}{ leaf petioles } & 2 & -0.21 & -0.22 & -0.03 & -0.08 & 0.08 & 0.05 & 0.09 & -0.14 & 0.22 & 0.16 & $\mathrm{NI}$ & NI & -0.26 & -0.01 & 0.31 & 0.01 & NI & NI \\
\hline & 3 & 0.06 & 0.02 & 0.17 & 0.08 & 0.01 & 0.01 & 0.03 & -0.03 & 0.05 & -0.01 & & & 0.01 & -0.01 & -0.07 & 0.01 & & \\
\hline Wounding & 1 & -0.84 & -0.02 & -0.21 & 0.12 & -0.90 & -0.86 & 0.82 & 0.70 & 0.86 & 0.80 & & & 0.36 & 0.13 & -0.29 & 0.03 & & \\
\hline \multirow[t]{2}{*}{ fruits } & 2 & -0.09 & 0.22 & -0.01 & 0.20 & 0.05 & -0.02 & 0.02 & -0.11 & 0.02 & -0.08 & NI & NI & -0.28 & -0.17 & 0.24 & 0.28 & NI & NI \\
\hline & 3 & 0.03 & 0.15 & 0.12 & -0.16 & 0.01 & 0.01 & 0.02 & 0.01 & 0.03 & 0.04 & & & 0.01 & 0.16 & -0.06 & -0.10 & & \\
\hline \multirow{3}{*}{$\begin{array}{l}\text { Wounding } \\
\text { stems }\end{array}$} & 1 & 0.08 & 0.03 & 0.29 & 0.09 & -0.86 & 0.69 & 0.68 & -0.59 & & & & & 0.80 & -0.42 & -0.68 & 0.53 & & \\
\hline & 2 & 0.12 & -0.28 & 0.13 & -0.07 & 0.02 & -0.03 & 0.11 & 0.05 & $\mathrm{NV}^{\mathrm{e}}$ & NV & $\mathrm{NI}$ & NI & -0.06 & 0.22 & 0.08 & -0.14 & NI & NI \\
\hline & 3 & 0.04 & -0.01 & -0.03 & 0.10 & -0.01 & -0.01 & -0.01 & 0.05 & & & & & 0.01 & 0.01 & 0.02 & 0.04 & & \\
\hline Wounding & 1 & -0.52 & 0.12 & 0.67 & 0.51 & -0.91 & -0.86 & 0.85 & 0.71 & & & & & 0.89 & 0.74 & -0.92 & -0.87 & & \\
\hline \multirow[t]{2}{*}{ buds } & 2 & -0.23 & -0.33 & 0.02 & 0.25 & -0.03 & -0.07 & 0.05 & 0.16 & NV & NV & NI & NI & 0.12 & 0.20 & -0.04 & -0.02 & NI & NI \\
\hline & 3 & 0.17 & 0.02 & 0.19 & 0.02 & 0.05 & -0.01 & 0.10 & 0.02 & & & & & 0.01 & -0.01 & 0.03 & -0.01 & & \\
\hline Wounding & 1 & -0.01 & -0.08 & 0.29 & -0.06 & -0.73 & 0.68 & 0.57 & -0.10 & & & & & 0.71 & -0.51 & -0.54 & 0.65 & & \\
\hline \multirow[t]{2}{*}{ leaf scars } & 2 & 0.48 & 0.32 & -0.15 & -0.02 & -0.01 & 0.05 & -0.28 & 0.09 & NV & NV & $\mathrm{NI}$ & NI & 0.01 & -0.09 & 0.08 & -0.04 & NI & NI \\
\hline & 3 & 0.03 & 0.01 & 0.17 & -0.17 & -0.02 & 0.01 & 0.05 & 0.16 & & & & & -0.05 & 0.10 & 0.13 & -0.05 & & \\
\hline
\end{tabular}

a $K=$ rate parameter and $B=$ initial amount of disease parameters ( $K$ and $B$ associated with the Gompertz model). AUDPC $=$ area under the disease progress curves ( $\%$ days).

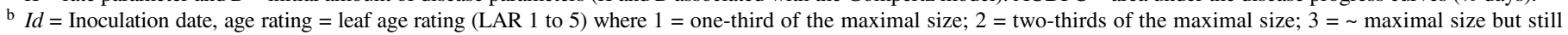
soft; 4 = maximal size, just hardened, and dark green; and $5=$ mature leaf, more than 2 months after tissue hardening or fruit age rating (FAR 1 to 5 ) where $1=$ young fruit less than 2 months following blossom; 2 = young green fruit in growth phase; 3 = fruit nearly full size but still green; $4=$ fruit full sized and beginning to turn color; and $5=$ mature, full sized, and colored fruit, $R_{n}=$ cumulative $\mathrm{cm}$ of rain for 2 weeks postinoculation, $T_{\min }=$ number of days during the first 2 weeks postinoculation for which the minimun temperature was less than $14^{\circ} \mathrm{C}, T_{\max }=$ number of days during the first 2 weeks postinoculation for which the maximum temperature was greater than $28^{\circ} \mathrm{C}, R_{90}=$ number of days during the first 2 weeks postinoculation for which the average relative humidity was greater than $90 \%$.

c Canonical variates of the other set of variables.

d $\mathrm{NI}=$ not included in the canonical analysis concerning the treatments with wounding.

e $\mathrm{NV}=$ no variation in the age of tissues over the observations. 
requirements for bacterial cell proliferation (14). Furthermore, for treatments where wounding preceded inoculation, bacteria were directly in contact with the high relative humidity and free water in intercellular spaces. Under Réunion Island conditions, the number of days during the first 2 weeks following inoculation for which the average relative humidity was less than $80 \%$ varied from 0 to 6 days over the 12 series of inoculations except for series 1 corresponding to the inoculation date of 4 October 1989 $\left(R H_{80}=11\right)$ and series 1 and $2\left(R H_{80}=13\right)$, respectively for the Pineapple sweet orange and the Tahiti lime plots in this trial.

Disease incidence was adequately represented by a single integrated variable, AUDPC, which takes into account many of the characteristics associated with the other epidemic variables that were eliminated. The AUDPC provided a quantitative measure of symptom development and was calculated regardless of the shape of the disease progress curve, whereas, other epidemic variables were dependent upon a model being fit to the data before they could be calculated. Consequently, the strength of AUDPC as a variable is that it may not be as sensitive to variations as the model-based variables. The Gompertz model was selected preliminarily to allow calculation of epidemic variables to be included in the multidimensional analysis. The Gompertz model was the most appropriate in the majority of cases as evidenced by the $d Y / d t$ curve (which describes the daily rate of symptom development), which was skewed to the right indicating that the disease progress curve was asymmetrically sigmoid and the majority of disease increase occurred later in the epidemic in the most cases. This asymmetry describing heterogeneity over time could be the consequence of modifications of the susceptibility of host tissue, different inoculum density, or climatic effects that favored the infection process (35). For this study, the dose of inoculum was experimentally controlled and constant. Therefore, the evolution of tissue susceptibility, i.e., due to healing process (33), maturation of tissues or other general resistance mechanisms, and climatic factors over the 84 days of disease assessment were most likely the strongest factors that induced the asymmetry expressed as a rapid increase in disease. Asymmetry in the responses seems to be the rule in pathology as indicated by a better statistical fit obtained with the Gompertz model for many sets of data including ACC epidemics $(3,21,23)$. The Gompertz model is often chosen for its simplicity and has a curve shape that closely approximate those of other models with more realistic terms (45). This makes it more flexible.

The disease as described by AUDPC could be predicted by a minimum set of environmental variables. The age of tissues at the time of infection was a good predictor for disease resulting from the spray inoculation method on fruits and leaves, which represents natural rain splash deposition of inoculum. The tissue age rating used in this study was consistent with previously reported stages inducing differential susceptibility $(17,52,60)$. The age of tissue was also a significant factor for determining disease on fruits following a wound inoculation. However, tissue age as a variable was not useful in determining disease development on leaves after wounding. Leaves of approximately two-thirds expansion were much more prone to water congestion and bacterial penetration than fully expanded leaves $(17,26)$. However, young leaves did not show any major differences in stomatal structure or number compared to mature leaves. It was shown that the increase in resistance to water congestion as leaves expanded beyond twothirds or their maximal size was the major factor of resistance to inoculation. The last stages of leaf expansion, i.e., two-thirds to full expansion were coincident with a rapid development of the cuticle and build-up of waxes around the natural openings (17, 26,36). However, wound inoculation brings the inoculum directly in contact with the leaf mesophyll tissue and weakens the difference in the response of the leaves according to the age of tissue. Pinprick inoculation of leaves bypasses bacterial penetration through stomatal openings by penetrating the leaf epidermis and introducing the bacteria directly into the mesophyll tissue. The resistance of species and cultivars of citrus to stomatal infection is no longer considered to be a function of stomatal size and number (18). Furthermore, mesophyll resistance is expressed in mature leaves as limiting the multiplication of bacteria and is variable among citrus species and cultivars (52).

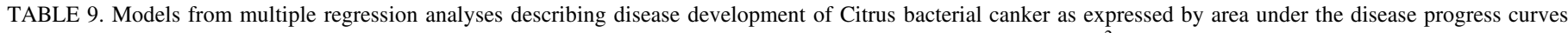
(AUDPC) using the selected environmental variables. The model selection method was performed with the maximum $R^{2}$ improvement technique

\begin{tabular}{|c|c|c|c|c|}
\hline \multirow[b]{2}{*}{ Cultivar and plant organ } & \multicolumn{2}{|r|}{ Best model for each individual treatment ${ }^{\mathrm{a}}$} & \multicolumn{2}{|c|}{$\begin{array}{l}\text { Best generalized model for each combination of inoculation } \\
\text { method and plant tissue }{ }^{b}\end{array}$} \\
\hline & $R^{2}$ & Model & $R^{2}$ & Model \\
\hline \multicolumn{5}{|l|}{ Spray inoculation } \\
\hline Sweet orange leaf & 0.566 & $y=46.333 * * * \mathrm{c}-7.372 x^{* * *}-0.583 u^{*}-0.950 w^{* *}$ & 0.566 & $y=46.333^{* * *}-7.372 x^{* * *}-0.583 u^{*}-0.950 w^{* *}$ \\
\hline Lime leaf & 0.865 & $y=70.169 * * *-0.049 z^{*}-18.522 x^{* * *}+3.119 u^{* * *}+2.312 w^{* *}$ & 0.848 & $y=81.734 * * *-19.088 x^{* * *}+1.421 u^{*}+1.141 w^{*}$ \\
\hline Sweet orange fruit & 0.922 & $y=86.121 * * *+0.244 z^{*}-31.044 x^{* * *}+1.154 u^{*}-2.714 w^{* * *}$ & 0.909 & $y=73.760 * * *-16.618 x^{* * *}+1.097 u^{\circ}-2.290 w^{* * *}$ \\
\hline Lime fruit & 0.87 & $y=84.584 * * *-17.247 x^{* * *}-4.024 u^{* * *}-2.099 w^{* * *}$ & 0.87 & $y=84.584 * * *-17.247 x^{* * *}-4.024 u^{* * *}-2.099 w^{* * *}$ \\
\hline \multicolumn{5}{|l|}{ Wound inoculation } \\
\hline Sweet orange leaf petiole & 0.665 & $y=83.058 * * *-0.089 z^{* * *}-0.858 u^{* * *}$ & 0.665 & $y=83.058^{* * *}-0.089 z^{* * *}-0.858 u^{* * *}$ \\
\hline Lime leaf petiole & 0.663 & $y=101.023^{* * *}-0.075 z^{* * *}-11.149 x^{* *}+1.840 w^{* * *}$ & 0.514 & $y=67.03 * * *-0.101 z^{* * *}-1.097 u^{* \mathrm{~d}}$ \\
\hline Lime leaf petiole & & & 0.644 & $y=42.768^{* * *}-0.125 z^{* * *}+1.657 u+2.471 w^{* * * \mathrm{e}}$ \\
\hline Sweet orange leaf lamina & 0.64 & $y=80.429 * * *-0.093 z^{* * *}-0.894 u^{* * *}$ & 0.64 & $y=80.429 * * *-0.093 z^{* * *}-0.894 u^{* * *}$ \\
\hline Lime leaf lamina & 0.589 & $y=41.492 * * *-0.148 z^{* * *}+2.376 u^{*}+3.164 w^{* * *}$ & 0.445 & $y=72.553^{* * *}-0.118 z^{* * *}-1.150 u^{* \mathrm{~d}}$ \\
\hline Lime leaf lamina & & & 0.589 & $y=41.492 * * *-0.148 z^{* * *}+2.376 u^{*}+3.164 w^{* * * \mathrm{e}}$ \\
\hline Sweet orange fruit & 0.849 & $y=114.263 * * *-17.604 x^{* * *}-2.921 u^{* * *}-2.838 w^{* * *}$ & 0.801 & $y=90.423^{* * *}-17.872 x^{* * *}-0.749 u^{\circ}$ \\
\hline Lime fruit & 0.73 & $y=56.802 * * *-12.120 x^{* * *}-1.051 w^{* * *}$ & 0.717 & $y=46.801 * * *-13.220 x^{* * *}+2.054 u^{* * *}$ \\
\hline Sweet orange stem & 0.759 & $y=49.809 * * *-0.054 z^{* * *}-1.914 \mathrm{u} * * *$ & 0.69 & $y=32.490 * * *-0.075 z^{* * *}+2.031 w^{* * *}$ \\
\hline Lime stem & 0.469 & $y=28.878^{* * *}-0.099 z^{* * *}+1.783 u^{*}+2.149 w^{* * *}$ & 0.419 & $y=39.334 * * *-0.071 z^{* * *}+1.087 w^{* *}$ \\
\hline Sweet orange petiole cut & 0.524 & $y=15.085^{* * *}-1.064 u^{* * *}-0.556 w^{*}$ & 0.355 & $y=6.652 * * *-0.017 z^{* *}+0.505 w^{* *}$ \\
\hline Lime petiole cut & 0.39 & $y=-2.356^{\mathrm{f}}+0.017 z^{*}+0.824 w^{* * *}$ & 0.302 & $y=5.933 * * *+0.026 z^{* *}-0.972 u^{* * *}$ \\
\hline Sweet orange bud & 0.843 & $y=1.474^{\circ}+2.232 w^{* * *}$ & 0.843 & $y=1.474^{\circ}+2.232 w^{* * *}$ \\
\hline Lime bud & 0.736 & $y=4.305^{* * *}+1.493 w^{* * *}$ & 0.736 & $y=4.305^{* * *}+1.493 w^{* * *}$ \\
\hline
\end{tabular}

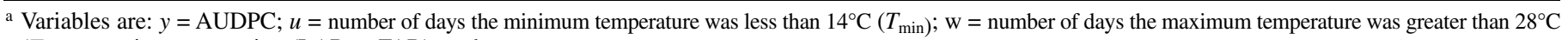
$\left(T_{\max }\right) ; x=$ tissue age rating (LAR or FAR); and $z=$ inoculation date $(I d)$.

b Selection of a best generalized model with common variables to represent each group of similar treatments for both citrus species.

${ }^{c}$ Significance of each predictor variable and intercept $-t$ tests had $*, P<0.05 ; * *, P<0.01 ; * * *, P<0.001 ;{ }^{\circ}, 0.05<P<0.10$.

d Best generalized common model for wounded leaves.

e Best generalized common model for wounded leaves of lime.

${ }^{\mathrm{f}} p$ (intercept) $=0.24$. 
Temperature, as expressed by $T_{\min }$ or $T_{\max }$, was also a significant factor in determining disease development described by AUDPC. Growth of $X$. axonopodis pv. citri in citrus tissues can occur at 6 to $36^{\circ} \mathrm{C}$ (34). Even though the temperature of $6^{\circ} \mathrm{C}$ only allows the bacteria to do little more than become established in plant tissues, the growth in planta that leads to lesion formation occurs between 15 and $36^{\circ} \mathrm{C}$. The optimum temperature for ACC lesion development is approximately $30^{\circ} \mathrm{C}$ and the maximum temperature is $35^{\circ} \mathrm{C}(38,41)$. During the present study, the range of $T_{\min }$ and $T_{\max }$ was 15.5 to $23.5^{\circ} \mathrm{C}$ and 19.7 to $31.8^{\circ} \mathrm{C}$, and 12.2 to $22^{\circ} \mathrm{C}$ and 19.7 to $30.7^{\circ} \mathrm{C}$, respectively, for the Tahiti lime and Pineapple sweet orange plots. Minimum temperatures did not often fall below those needed for growth, and maximum temperatures approached but did not exceed the optimum temperature. However, considering the same mature organs, disease incidence after 84 days varied from 0.46 to 1.0 and from 0.16 to 0.98 , respectively, on the leaves and stems of Pineapple sweet oranges following a needle-prick inoculation, and disease incidence for the leaves of Tahiti lime varied from 0.10 to 0.98 . Therefore, the temperature ranges experienced during the experiment likely affected lesion development by influencing the rate of bacterial growth. The monthly values of disease variables like $Y 28, K$ or AUDPC estimated for mature leaves or stems following a wound inoculation decreased greatly during the series of inoculations 8 to 11 (inoculation date between 30 May and 8 August). The lowest cumulative $T_{\min }$ and $T_{\max }$ occurred during these months, and relatively low temperature acted as a limiting factor. The lower temperatures delayed the onset of disease expression, which is illustrated by a great increase of $t_{50}$ after inoculations from May to August. Thus, latent period for ACC symptom expression seems to be most likely primarily a function of temperature (31). All of the models, which described the symptom development, were based on the temperature assessed by the minimum or the maximum temperature, or both variables.

Surprisingly, relative humidity was not retained after canonical correlation analysis as a meaningful environmental variable for disease expression even on combinations associated with the spray treatment. This corroborates previous experiments showing that relative humidity did not affect $X$. axonopodis pv. citri survival on leaves and leaf infection (55) and our previous conclusion that sufficient free moisture for bacterial survival was omnipresent.

Penetration of the host plant surface by the bacteria is accomplished through natural openings, e.g., stomates or surface wounds $(14,46)$. In this study, we used two methods that simulated natural methods of infection. Spray inoculation was intended to reproduce infection that occurs by splash dispersal or wind-driven rain. Wounding methods were intended to reproduce the effects of the thorn scratches that occur during strong winds or other mechanical injuries. Neither method overwhelmed the tissues, that is, both methods appeared to introduce only a few bacteria into the plant tissues (17). The effect of wounding is particularly important on mature leaves, which are resistant to stomatal infection. The reaction of fruit to wounding is somewhat different. The needle-prick method of inoculation increased the susceptibility of the fruit over a longer period. However, it did not overcome a general resistance of fruit that was nearing maturity. Previous descriptions of fruit susceptibility to ACC are primarily based on field observations which demonstrated that fruits 2 to $4 \mathrm{~cm}$ in diameter were the most susceptible and that fruit became more resistant as size increased (24). Moreover, inoculation of mature fruits resulted in less erumpent and nontypical lesions (12). The present study was based on a systematic comparison of disease following fruit inoculation and provided a means to quantify the level of susceptibility according to the age of tissue and inoculation method. Young fruits (15 to $20 \mathrm{~mm}$ in diameter) of Pineapple sweet oranges inoculated by needle-prick method were less susceptible to infection compared to fruits in the 2 to $4 \mathrm{~cm}$ in diameter size, i.e., the maximum susceptibility range. However, the smallest fruits (15 to $20 \mathrm{~mm}$ ) inoculated by the spray method were the most susceptible to infection. This high susceptibility observed for these young fruits decreased with maturity. For the spray inoculation method, a strong decrease was noticeable on the fruits when they reached a diameter of approximately $50 \mathrm{~mm}$. This is due to decreased susceptibility to water soaking which is affected by the decrease of stomata development and the wax build up on the fruit surface (25). In the absence of wounding, little new disease was expressed on mature leaves. The relatively high disease incidence that was observed on the LAR 5 leaves of Tahiti lime following a spray inoculation for only one series $\left(Y_{f}\right.$ of series $\left.5=0.325\right)$ can be explained by the simultaneous presence of LAR 2 leaves and FAR 1 fruits at the date of inoculation. The young tissues of the trees quickly became infected and produced a large amount of inoculum that acted as a continual inoculum source and thus affected the mature leaves.

Susceptibility of other tissues was examined following wounding inoculations. Susceptibility of the fully developed greenwood following wounding was similar to that of leaves. Additionally, stomatal infection of stems was restricted to the period of shoot expansion. The relatively high susceptibility of nonlignified stems is important epidemiologically because stems can act as a reservoir of inoculum for longer periods than fruits and leaves. Buds and leaf scars expressed the lowest susceptibility among all the organs tested. The tree retains citrus leaves for two to four seasons. However, tissues at the leaf petiole scars are mostly callused at the time when leaf drop occurs and thus, the leaf abscission zone does not represent an important entrance point for $X$. axonopodis pv. citri. In other pathosystems, leaf scars can constitute an important entrance for infection. X. arboricola pv. pruni can efficiently penetrate by the leaf scars and late infections during autumn result in canker development in spring following a latent period (11).

We have proposed models to predict symptom development according to environmental factors. These variables were selected after multiple regression based on the production of the maximum $R^{2}$ and may not have any biological significance (6), but the assisted selection by an exploratory step (PCA) and a reduction step (CCA) was useful to identify variables, which are biologically realistic. Temperatures and tissue age are known to influence ACC disease expression as reported above. The selection of AUDPC as disease variable appeared to be the most meaningful. This can be understood because this variable retains the maximum information relative to an epidemic, i.e., disease onset, rate of increase, and final disease incidence (6). Further information will be needed to make these models more relevant, e.g., the minimal disease incidence necessary to initiate significant disease development and the evaluation of the available amount of inoculum in the lesions. Old lesions exude fewer bacteria and release them more slowly than young lesions (54). In addition, overwintering was shown to cause a marked decline of bacterial populations within the lesions in Argentina or Japan $(31,54)$, but recent results obtained on Réunion Island indicate that populations in canker lesions exposed to mild winter temperatures prevailing in a tropical environment are not strongly negatively affected (42). Concentration of inoculum necessary to cause infection is lower for young tissues than for mature tissues (17). Stomatal infection of a two-thirds expanded leaf was successful with $10^{4} \mathrm{CFU} / \mathrm{ml}$ of inoculum while $10^{6} \mathrm{CFU} / \mathrm{ml}$ of inoculum did not result in infection of a fully expanded leaf. Estimation of the quantity and availability of inoculum in the orchard and of the ratio of young tissue/mature tissue will be helpful for determining the strategy of ACC control to be applied.

This study further confirmed that to decrease the incidence of ACC in the orchards, cultural practices will have to reduce the wound formation and the simultaneous presence of young tissue and high level of $X$. axonopodis pv. citri populations. Windbreaks significantly reduced the disease increase (22). Biotic agents, such 
as the larvae of the citrus leaf miner, penetrate the epidermis of the leaves and expose the mesophyll to the ACC bacterium $(19,48)$. In addition, citrus leaf miner wounds heal more slowly than other mechanical wounds (33). Production of young tissues is induced by vigorous rootstocks (1) or some cultivars with a greater frequency and duration of leaf flush $(26,60)$. Young trees in the field and citrus plants under nursery conditions grow almost continuously, producing new susceptible tissues, thus epidemic progress is not limited by the availability of susceptible plant tissues $(23,32)$. The association of high susceptibility of the citrus trees to ACC with periods of growth was the basis of a proposed control method of timing of copper sprays related to the presence of young tissues (53).

\section{ACKNOWLEDGMENTS}

We thank G. M. de Aguilera for modeling suggestions, A. Couteau for skillful technical assistance, and C. Dubois and X. Perrier from CIRAD for helpful consultation.

\section{LITERATURE CITED}

1. Agostini, J. P., Graham, J. H., and Timmer, L. W. 1985. Relationship between development of citrus canker and rootstock cultivar for young 'Valencia' orange trees in Misiones, Argentina. Proc. Fla. State Hortic. Soc. 98:19-22.

2. Alvarez, A. M., Benedict, A. A., Mizumoto, C. Y., Pollard, L. W., and Civerolo, E. L. 1991. Analysis of Xanthomonas campestris pv. citri and X. c. citrumelo with monoclonal antibodies. Phytopathology 81:857-865.

3. Berger, R. D. 1981. Comparison of the Gompertz and logistic equations to describe plant disease progress. Phytopathology 71:717-719.

4. Broabent, P., Fahy, P. C., Gillings, M. R., Bradley, J. K., and Barnes, D. 1992. Asiatic citrus canker detected in a pummelo orchard in northern Australia. Plant Dis. 76:824-829.

5. Brun, J. 1971. Le chancre bactérien des Citrus. Fruits 26:533-540.

6. Campbell, C. L., and Madden, L. V. 1990. Introduction to Plant Disease Epidemiology. John Willey \& Sons, New York.

7. Campbell, C. L., Madden, L. V., and Pennypacker, S. P. 1980. Structural characterization of bean root rot epidemics. Phytopathology 70:152-155.

8. Canteros, B. I. 1992. Changes in the resistance of developing citrus fruit to canker. Proc. Int. Soc. Citriculture 2:825-827.

9. Civerolo, E. L. 1984. Bacterial canker disease of citrus. J. Rio Grande Val. Hortic. Soc. 37:127-146.

10. Cook, A. A. 1988. Association of citrus canker pustules with leaf miner tunnels in North Yemen. Plant Dis. 72:546.

11. Feliciano, A., and Daines, R. H. 1970. Factors influencing ingress of Xanthomonas pruni through peach leaf scars and subsequent development of spring cankers. Phytopathology 60:1720-1726.

12. Fulton, H. R., and Bowman, J. J. 1929. Infection of fruit of Citrus by Pseudomonas citri. J. Agric. Res. 39:403-426.

13. Gillings, M. R., Fahy, P. C., Broadbent, P., and Barnes, D. 1995. Rapid identification of a second outbreak of asiatic citrus canker in the Northern Territory using the polymerase chain reaction and genomic fingerprinting. Aust. Plant Pathol. 24:104-111.

14. Goodman, R. N. 1982. The infection process. Pages 31-62 in: Phytopathogenic Prokaryotes Vol. 1, M. S. Mount and G. H. Lacy, eds. Academic Press, London.

15. Goto, M. 1992. Citrus canker. Pages 170-208 in: Diseases of Fruit Crops-Plant Diseases of International Importance. Vol. III, J. Kumar, H. S. Chaube, U. S. Singh, and A. N. Mukhopadhyay, eds. Prentice Hall, Englewood Cliffs, NJ.

16. Goto, M., Takahashi, T., and Messina, M. A. 1980. A comparative study of the strains of Xanthomonas campestris pv. citri isolated from citrus canker in Japan and cancrosis B in Argentina. Ann. Phytopathol. Soc. Jpn. 46:329-338.

17. Gottwald, T. R., and Graham, J. H. 1992. A device for precise and nondisruptive stomatal inoculation of leaf tissues with bacterial pathogens. Phytopathology 82:930-935.

18. Gottwald, T. R., Graham, J. H., Civerolo, E. L., Barrett, H. C., and Hearn, C. J. 1993. Differential host range of citrus and citrus relatives to citrus canker and citrus bacterial spot determined by leaf mesophyll susceptibility. Plant Dis. 77:1004-1009.

19. Gottwald, T. R., Graham, J. H., and Schubert, T. S. 1997. An epidemiological analysis of the spread of citrus canker in urban Miami, Florida, and synergistic interaction with the Asian citrus leaf miner. Fruits 52:371-378.
20. Gottwald, T. R., Hughes, G., Graham, J. H., Sun, X., and Riley, T. 2001. The citrus canker epidemic in Florida: The scientific basis of regulatory eradication policy for an invasive species. Phytopathology 91:30-34.

21. Gottwald, T. R., McGuire, R. G., and Garran, S. 1988. Asiatic citrus canker: Spatial and temporal spread in simulated new planting situations in Argentina. Phytopathology 78:739-745.

22. Gottwald, T. R., and Timmer, L. W. 1995. The efficacy of windbreaks in reducing the spread of citrus canker caused by Xanthomonas campestris pv. citri. Trop. Agric. 72:194-201.

23. Gottwald, T. R., Timmer, L. W., and McGuire, R. G. 1989. Analysis of disease progress of citrus canker in nurseries in Argentina. Phytopathology 79:1276-1283.

24. Graham, J. H., and Gottwald, T. R. 1991. Research perspectives on eradication of citrus bacterial diseases in Florida. Plant Dis. 12:11931200.

25. Graham, J. H., Gottwald, T. R., and Riley, T. R. 1992. Susceptibility of citrus fruit to bacterial spot and citrus canker. Phytopathology 82:452457.

26. Graham, J. H., Gottwald, T. R., Riley, T. R., and Achor, D. 1992. Penetration through leaf stomata and growth of strains of Xanthomonas campestris strains in citrus cultivars varying in susceptibility to bacterial diseases. Phytopathology 82:1319-1325.

27. Hartung, J. S., and Civerolo, E. L. 1989. Restriction fragment length polymorphism distinguish Xanthomonas campestris strains isolated from Florida citrus nurseries from $X$. c. pv. citri. Phytopathology 79:793-799.

28. Kleinbaum, D. G., Kupper, L. L., and Muller, K. E. 1988. Applied Regression Analysis and Other Multivariable Methods. 2nd ed. PWSKent Publishing Co., Boston.

29. Koizumi, M. 1972. Studies on the symptoms of citrus canker formed on satsuma mandarin fruit and existence of causal bacteria in the affected tissues. Bull. Hortic. Res. Stn. Ser. B 12:229-243.

30. Koizumi, M. 1976. Incubation period of citrus canker in relation to temperature. Bull. Fruit Tree Res. Stn. Ser. B (Okitsu) 3:33-46.

31. Koizumi, M. 1977. Relation of temperature to the development of citrus canker in the spring. Proc. Int. Soc. Citriculture 3:924-928.

32. Koizumi, M. 1981. Resistance of citrus plants to bacterial canker disease: A review. Proc. Int. Soc. Citriculture 1:402-405.

33. Koizumi, M. 1983. Relationship between wound-healing process of citrus leaf tissues and successful infection through wounds by Xanthomonas campestris pv. citri (hasse) Dye. Ann. Phytopathol. Soc. Jpn. 49:352-360.

34. Koizumi, M. 1985. Citrus canker: The world situation. Pages 2-7 in: Citrus Canker: An International Perspective. L. W. Timmer, ed. Univ. Fla. Inst. Food Agric. Sci., Gainesville.

35. Kranz, J. 1974. Comparison of epidemics. Annu. Rev. Phytopathol. 12:355-374.

36. Lee, H. A. 1922. Relation of the age of citrus tissues to the susceptibility to citrus canker. Philipp. J. Sci. 20:331-339.

37. Leite, R. P., Egel, D. S., and Stall, R. E. 1994. Genetic analysis of hrprelated DNA sequences of Xanthomonas campestris strains causing diseases of citrus. Appl. Environ. Microbiol. 60:1078-1086.

38. Loucks, K. W. 1930. Some physiological studies of Phytomonas citri. J. Agric. Res. 41:247-258.

39. McLean, F. T., and Lee, A. H. 1921. The resistance to citrus canker of Citrus nobilis and a suggestion as to the production of resistant varieties in other Citrus species. Phytopathology 11:109-114.

40. Mora-Aguilera, G., Nieto-Angel, D., Campbell, C. L., Teliz, D., and Garcia, E. 1996. Multivariate comparison of papaya ringspot virus epidemics. Phytopathology 86:70-78.

41. Peltier, G. L. 1920. Influence of temperature and humidity on the growth of Pseudomonas citri and its host plants and on infection and development of the disease. J. Agric. Res. 20:447-506.

42. Pruvost, O., Boher, B., Brocherieux, C., Nicole, M., and Chiroleu, F. 2002. Survival of Xanthomonas axonopodis pv. citri in leaf lesions under tropical environmental conditions and simulated splash dispersal of inoculum. Phytopathology 92:336-346.

43. Pruvost, O., Gottwald, T. R., and Brocherieux, C. 1999. The effect of irrigation practices on the spatio-temporal increase of Asiatic citrus canker in simulated nursery plots in Reunion Island. Eur. J. Plant Pathol. 105:23-37.

44. Pruvost, O., Hartung, J. S., Civerolo, E. L., Dubois, C., and Perrier, X. 1992. Plasmid DNA fingerprints distinguish pathotypes of Xanthomonas campestris pv. citri, the causal agent of citrus bacterial canker disease. Phytopathology 82:485-490.

45. Rouse, D. I. 1985. Construction of temporal models: I. Disease progress of air-borne pathogens. Pages 11-29 in: Advances in Plant Pathology Vol. 3, Mathematical Modeling of Crop Disease. C. A. Gilligan, ed. Academic press, London.

46. Rudolph, K. 1993. Infection of the plant by Xanthomonas. Pages 193- 
264 in: Xanthomonas. J. G. Swings and E. C. Civerolo, eds. Chapman and Hall, London.

47. Schubert, T. S., Miller, J. W., and Gabriel, D. W. 1996. Another outbreak of bacterial canker on citrus in Florida. Plant Dis. 80:1208.

48. Schubert, T. S., Rizvi, S. A., Sun, X., Gottwald, T. R., Graham, J. H., and Dixon, W. N. 2001. Meeting the challenge of eradicating citrus canker in Florida-Again. Plant Dis. 85:340-356.

49. Serizawa, S., and Inoue, K. 1976. Studies on citrus canker. III. The influence of wind on infection. Bull. Shizuoka Pref. Citrus Exp. Sta. 11:54-67.

50. Serizawa, S., Inoue, K., and Goto, M. 1969. Studies on citrus canker disease. I. Dispersal of the citrus canker organism. Bull. Fac. Agric. Shizuoka Univ. 8: 81-85.

51. Stall, R. E., and Civerolo, E. L. 1991. Research relating to the recent outbreak of Citrus canker in Florida. Annu. Rev. Phytopathol. 29:339420.

52. Stall, R. E., Marcos, G. M., and Canteros de Echenique, B. I. 1982. Importance of mesophyll in mature-leaf resistance to cancrosis of citrus. Phytopathology 72:1097-1100.

53. Stall, R. E., Miller, J. W., Marco, G. M., and Canteros de Echenique, B. I. C. 1981. Timing of sprays to control cancrosis of grapefruit in Argentina. Proc. Int. Soc. Citriculture 1:414-417.

54. Timmer, L. W., Gottwald, T. R., and Zitko, S. E. 1991. Bacterial exudation from lesions of asiatic citrus canker and citrus bacterial spot.
Plant Dis. 75:192-195.

55. Timmer, L. W., Zitko, S. E., and Gottwald, T. R. 1996. Population dynamics of Xanthomonas campestris pv. citri on symptomatic and asymptmatic citrus leaves under various environmental conditions. Proc. Int. Soc. Citriculture 1:448-451.

56. Vauterin, L., Hoste, B., Kersters, K and Swings, J. 1995. Reclassification of Xanthomonas. Int. J. Syst. Bacteriol. 45:472-489.

57. Vernière, C., Hartung, J. S., Pruvost, O. P., Civerolo E. L., Alvarez, A. M., Maestri, P., and Luisetti, J. 1998. Characterization of phenotypically distinct strains of Xanthomonas axonopodis pv. citri from southwest Asia. Eur. J. Plant Pathol. 104:477-487.

58. Vernière, C., Pruvost, O., Civerolo, E. L., Gambin, O., JacquemoudCollet, J. P., and Luisetti, J. 1993. Evaluation of the Biolog substrate utilization system to identify and assess metabolic variation among strains of Xanthomonas campestris pv. citri. Appl. Environ. Microbiol. 59:243-249.

59. Wiehe, P. O. 1941. Report on plant pathologist's visit to Rodrigues.

60. Zubrzycki, H. M., and Diamante de Zubrzycki, A. 1981. Resistance to Xanthomonas campestris pv citri (Hasse) Dawson in oranges [Citrus sinensis (L.) Osbeck]. Proc. Int. Soc. Citriculture 1:405-409.

61. Zubrzycki, H. M., and Diamante de Zubrzycki, A. 1987. Relationship between the amount of inoculum and the infection caused by Xanthomonas campestris pv. citri on citrus seedlings through natural infections in the field. Proc. Int. Soc. Citriculture 1:379-382. 